\title{
ARTIFICIAL HYDRAULIC LIME BINDER AND ITS IMPACT ON PROPERTIES OF HEMP-LIME COMPOSITIONS
}

\author{
Maris Sinka $^{1}$, Genadijs Sahmenko ${ }^{2}$, Aleksandrs Korjakins ${ }^{3}$, Līga Upeniece ${ }^{4}$ \\ ${ }_{1,2,3,4}$ Riga Technical University, Institute of Materials and Structures, Chair of Building Materials and Products, \\ Kalku Str. 1, LV-1658, Riga, Latvia

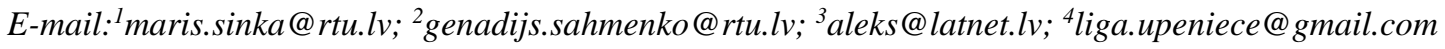

\begin{abstract}
The rising global temperature is partly associated with the increase of anthropogenic carbon dioxide $\left(\mathrm{CO}_{2}\right)$ emissions. Major part of this $\mathrm{CO}_{2}$ comes from building material industry and from energy consumed to maintain buildings. To solve this problem a building material that both has low thermal conductivity and emits low amount of $\mathrm{CO}_{2}$ is needed. Hemp and hydraulic lime building materials are one of these materials, but they are not widely used partly due to insufficient research of their possible properties. The aim of this research was to find optimal composition of artificial hydraulic lime binder and to elaborate appropriate compositions of hemp-lime insulating material. The binder itself was also to be tested as multiple air limes were supplemented with different additives and the most appropriate for use in hemp-lime material was to be chosen - a dolomitic lime DL60 with 40\% metakaolin additive. The ratio of hemp/binder 0.38 gave the best results - compressive strength of $0.221 \mathrm{MPa}$ at $10 \%$ deformation and thermal conductivity of $0.0757 \mathrm{~W} / \mathrm{m}^{2} \mathrm{k}$, which is considered a good result and shows a possibility for this material to be used as self-bearing thermal insulation building material.
\end{abstract}

Keywords: hydraulic lime, hemp shives, pozzolans, CO2 absorption, hemp, thermal insulation

\section{Introduction}

One of the challenges that have to be faced by the modern society is global increase of $\mathrm{CO}_{2}$ and temperature growth that is associated with it. Nowadays, it is getting recognised that these two things are connected (Humlum et al 2013), the debate now shifts to the question of the extent to which carbon dioxide accumulation boosts the global temperature rise (Florides et al 2013), nevertheless it is acknowledged that we should reduce the anthropogenic $\mathrm{CO}_{2}$ emissions to minimise the temperature ascent (Hook, Tang 2013).

Construction industry is one of the largest $\mathrm{CO}_{2}$ emitters for example in China, which is the largest carbon dioxide pollutant (Wang et al. 2013), construction industry is responsible for more than $15 \%$ of all greenhouse gas emissions ( $\mathrm{Xu}$ et al. 2012). In the US, which is the second largest emitter (Benhelal et al. 2013), construction industry is responsible for the third highest carbon emissions among industrial sectors. Cement industry alone is responsible for $5-7 \%$ of global $\mathrm{CO}_{2}$ pollution.

In more indirect way construction industry contributes to increasing quantity of $\mathrm{CO}_{2}$ by failing to quickly apply building materials that can lower the amount of heat necessary to be produced as heating together with electricity and water heating generates $36 \%$ of all $\mathrm{CO}_{2}$ emissions in Latvia, 50\% in the UK (Bushbridge 2009), $45 \%$ in Canada, $40 \%$ in the USA, and $20 \%$ in China (Glaeser et al. 2009).

To deal with the problems mentioned above, the building material industry needs to develop solutions. One of the ways how to solve this problem is hemp-lime material, which is made of hemp shives and hydraulic lime. It has good thermal conductivity for heat loss reduction and it can be produced with low $\mathrm{CO}_{2}$ amount. In Figure 1 hemp-lime composition with three main $\mathrm{CO}_{2}$ flows can be seen, which represent most significant carbon dioxide emission and absorption processes in hemp-lime manufacturing.
The inner part of the hemp stalk is called hemp shives, which is a filler of hemp-lime material, by chemical composition it is similar to wood pulp because it contains a lot of lignin (Stevulova et al. 2012). As it does not have many applications, it is considered an industrial byproduct from hemp fibre and seeds manufacture. The main usage of hemp shives is as a bedding material in horse stables due to their high moisture (Pejic et al. 2008) and smell absorptivity. It is due to their highly porous structure that hemp shives have these abilities and it is the reason why they are so appropriate as a thermal insulation building material.

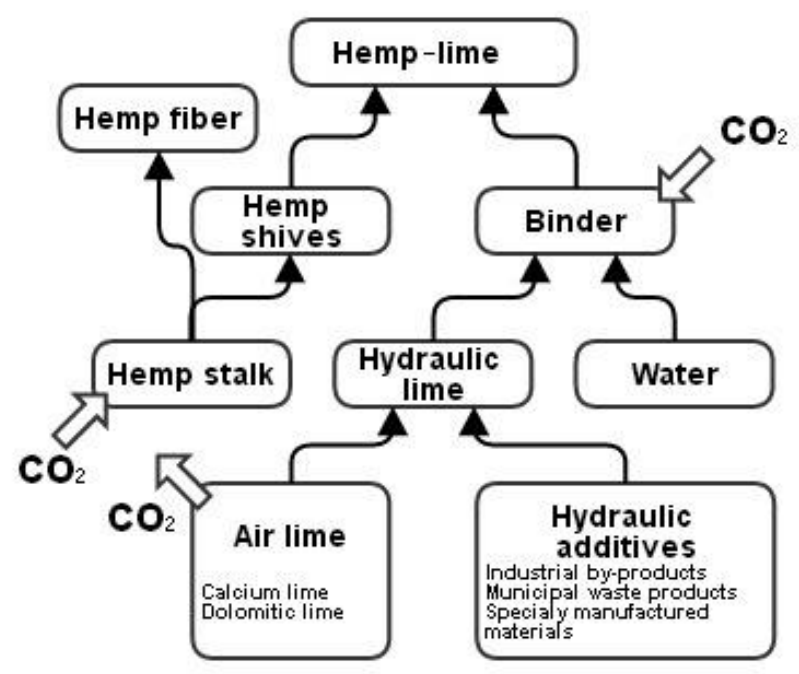

Fig. 1. Main $\mathrm{CO}_{2}$ flows in the hemp-lime composite.

Lime is an appropriate binder for hemp-lime material, because of its properties. First of all, a lot less carbon is emitted in its manufacturing process than producing other binders, such as cement - for 1 ton of hydrated lime $337 \mathrm{~kg}$ of $\mathrm{CO} 2$ are created, for cement $-819 \mathrm{~kg}$ (Wilkinson 2009). Secondly, when lime hardens, it 
reabsorbs carbon dioxide that was released in the burning process from limestone, through carbonization. And thirdly, excellent water vapour permeability of the hardened lime binder (Mosquera et al. 2004) makes it fully compatible with hemp shives to create a material with good moisture regulating properties.

Artificial hydraulic lime can be made by mixing air lime with hydraulic additives to make it stronger and more appropriate as a self-bearing hemp-lime binder. Most important properties of hydraulic additives are high amorphous $\mathrm{SiO}_{2}$ amount and small particle size (Walker, Pavia 2010). Commonly used additives for lime are silica fume (Wilkinson 2009), metakaolin (Cerny et al. 2006), fly-ash (Vejmelkova et al. 2012), various ground glass (Wegian et al. 2011) and ground brick (Wilkinson 2009).

As for total $\mathrm{CO} 2$ emitted by hemp-lime material, research shows that in fact this material absorbs, through growing of hemp stalk and carbonization of lime, more carbon dioxide than is emitted. Various researchers propose different amounts of $\mathrm{CO} 2$ sequestered in full life cycle of material in $1 \mathrm{~m} 3-4 \mathrm{~kg}$ (Edwards 2007), $108 \mathrm{~kg}$ (Bushbridge 2009), $120 \mathrm{~kg}$ (Miskin 2009) - as they use different calculation methods, but one thing is clear hemp-lime materials are carbon neutral or even negative.

The aim of this research first of all is to examine the effect of hydraulic additives on compressive strength on various air limes, to compare it with previously known hemp-lime binder strengths and to choose the most suitable for further research. Hemp-lime heat insulating materials are prepared with locally available resources in order to investigate their density, thermal conductivity and compressive strength. Various binder proportions are prepared to find the correlation between compressive strength, binder properties, density and thermal conductivity.

\section{Materials and methods}

\subsection{Material properties}

Three different commercially available air limes were used to find out the effect of lime content on hydraulic compound formation, composition of the limes are given in Table 1.

Table 1. Lime used in sample preparation.

\begin{tabular}{llllll}
\hline & $\begin{array}{l}\mathrm{CaO}+ \\
\mathrm{MgO} \\
\text { Name } \\
\%\end{array}$ & $\begin{array}{l}\text { Acti } \\
-\mathrm{ve} \\
\text { lime } \\
, \%\end{array}$ & $\begin{array}{l}\text { Bulk } \\
\text { density, } \\
\mathrm{kg} / \mathrm{m}^{3}\end{array}$ & Color & Producer \\
\hline $\begin{array}{l}\text { Hydrated } \\
\text { lime } \\
\text { CL90 }\end{array}$ & $\geq 90$ & $\geq 80$ & 627 & white & $\begin{array}{l}\text { Lhoist } \\
\text { Bukowa, PL }\end{array}$ \\
$\begin{array}{l}\text { Hydrated } \\
\text { lime } \\
\text { CL80 }\end{array}$ & $\geq 80$ & $\geq 65$ & 417 & white & $\begin{array}{l}\text { Krasnosolsk- } \\
\text { strojmateriali }\end{array}$ \\
\hline $\begin{array}{l}\text { Quicklim } \\
\text { e DL60 }\end{array}$ & $\geq 60$ & $\mathrm{X}$ & 807 & grey & $\begin{array}{l}\text { Saulkalne, } \\
\text { LV }\end{array}$ \\
\hline
\end{tabular}

Five different materials were used as hydraulic additives:

1. Silica fume or Microsilica (MS) - Elkem Microsilica 971 (undensified), Norway;

2. Metakaolin (MK) - industrial by-product, calcined at $800^{\circ} \mathrm{C}$ kaolin clay, Lithuania;

3. Chamotte $(\mathrm{CH})$ - mix for fireproof mortar, Ukraine;

4. Crushed fireproof brick (FB) - ground in laboratory ball mill at $300 \mathrm{rpm}, 30 \mathrm{~min}$;

5. Crushed hallow loadbearing (HB) - ground in the laboratory ball mill at $300 \mathrm{rpm}, 30 \mathrm{~min}$.

Hemp shives were obtained as by-product of hempfibre manufacture. Bulk density of the used hemp shives is $97 \mathrm{~kg} / \mathrm{m}^{3}$. Particle size distribution of hemp material can be seen in Table 2 and in Figure 2.

Table 2. Particle size distribution of the used hemp shives

\begin{tabular}{lccccccc}
\hline $\begin{array}{l}\text { Length, } \\
\mathrm{mm}\end{array}$ & $0-5$ & $5-10$ & $10-15$ & $15-20$ & $20-30$ & $30-40$ & $>40$ \\
\hline $\begin{array}{l}\% \text { of } \\
\text { mass }\end{array}$ & 27 & 15 & 14 & 19 & 13 & 8 & 4 \\
\hline
\end{tabular}

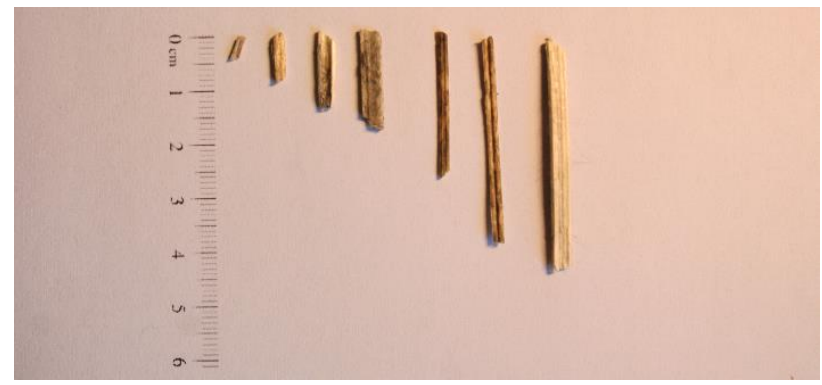

Fig. 2 Particle size distribution of used hemp shives.

\subsection{Experimental methods}

To test the ability of hydraulic additions to react with air, lime samples - prisms were made. Dimensions of the samples were $160 \times 40 \times 40 \mathrm{~mm}$, oiled steel moulds were used. Mixing of specimens was done manually, water was added as necessary to ensure a constant plastic consistency of mortar, so no mechanical vibration tools were needed.

After casting in moulds, specimens were covered with polyethylene film, kept for 7 days, then demoulded, sprayed with water and again covered with film to ensure constant high relative humidity $(95 \pm 5 \%)$, which was measured with the hygrometer.

Compressive strength of the samples (4 samples for each composition) was tested after 28 days of curing in accordance with standard (LVS 459-1:2011), tolerance of force determination $\pm 1 \%$. The binder with highest performance was selected for furtherer tests.

During the experiment three different hemp-lime compositions were made, to test the influence of material density on thermal conductivity and compressive strength, various binder proportions were tested. 
Table 3. Composition to test the reactivity of the limes

\begin{tabular}{lcccccc}
\hline $\begin{array}{l}\text { Sample } \\
\text { name }\end{array}$ & $\begin{array}{c}\text { Lime, } \\
\text { type }\end{array}$ & $\begin{array}{c}\text { Lime, } \\
\mathrm{g}\end{array}$ & $\begin{array}{c}\text { Meta., } \\
\mathrm{g}\end{array}$ & $\begin{array}{c}\text { Sand, } \\
\mathrm{g}\end{array}$ & $\begin{array}{c}\text { Water, } \\
\mathrm{g}\end{array}$ & $\begin{array}{c}\text { Hydr. } \\
\text { add., } \\
\%\end{array}$ \\
\hline C0 & CL90 & 300 & 0 & 600 & 266 & $0 \%$ \\
\hline C1 & CL90 & 285 & 15 & 600 & 266 & $5.0 \%$ \\
\hline C2 & CL90 & 270 & 30 & 600 & 266 & $10.0 \%$ \\
\hline C3 & CL90 & 240 & 60 & 600 & 266 & $20.0 \%$ \\
\hline C4 & CL80 & 300 & 0 & 600 & 300 & $0 \%$ \\
\hline C5 & CL80 & 285 & 15 & 600 & 300 & $5.0 \%$ \\
\hline C6 & CL80 & 270 & 30 & 600 & 300 & $10.0 \%$ \\
\hline C7 & CL80 & 240 & 60 & 600 & 300 & $20.0 \%$ \\
\hline C8 & DL60 & 300 & 0 & 600 & 200 & $0 \%$ \\
\hline C10 & DL60 & 285 & 15 & 600 & 200 & $5.0 \%$ \\
\hline C11 & DL60 & 270 & 30 & 600 & 200 & $10.0 \%$ \\
\hline
\end{tabular}

Drum mixer was used to mix the samples. First of all, hemp shives were put in the mixer with a half of the necessary amount of water and mixed for 3 minutes.

Then the binder was added, mixed for 2 minutes, and after all the rest of the water was added. Preparation continued until the binder was evenly distributed, which took 3-4 minutes. The mixed compositions were cast in oiled steel moulds with dimensions of 100x100x100 mm for compressive strength testing, and in $350 \times 350 \mathrm{~mm}$ water-proof plywood moulds for thermal conductivity testing. Material was cast in three layers, moderately tamping each layer, polyethylene film was placed on the top to avoid fast drying of the samples, then a steel plate with the weight was placed on the top for even compaction.

The film and weight were removed after 3 days, specimens were demoulded after 7 days of curing. Hardening conditions were: $20 \pm 2^{\circ} \mathrm{C}$ temperature and $55 \pm 10 \%$ relative humidity.
Table 5. Composition of dolomitic lime with metakaolin

\begin{tabular}{lcccccc}
\hline $\begin{array}{l}\text { Sample } \\
\text { name }\end{array}$ & $\begin{array}{c}\text { Lime, } \\
\text { type }\end{array}$ & $\begin{array}{c}\text { Lime, } \\
\mathrm{g}\end{array}$ & $\begin{array}{c}\text { Meta., } \\
\mathrm{g}\end{array}$ & $\begin{array}{c}\text { Sand, } \\
\mathrm{g}\end{array}$ & $\begin{array}{c}\text { Water, } \\
\mathrm{g}\end{array}$ & $\begin{array}{c}\text { Hydr. } \\
\text { add., } \\
\%\end{array}$ \\
\hline DL0 & DL60 & 350 & 0 & 700 & 240 & $0 \%$ \\
\hline DL1 & DL60 & 332.5 & 17.5 & 700 & 240 & $5.0 \%$ \\
\hline DL2 & DL60 & 315 & 35 & 700 & 240 & $10.0 \%$ \\
\hline DL3 & DL60 & 280 & 70 & 700 & 240 & $20.0 \%$ \\
\hline DL4 & DL60 & 245 & 105 & 700 & 240 & $30.0 \%$ \\
\hline DL5 & DL60 & 210 & 140 & 700 & 240 & $40.0 \%$ \\
\hline DL6 & DL60 & 175 & 175 & 700 & 240 & $50.0 \%$ \\
\hline DL7 & DL60 & 140 & 210 & 700 & 240 & $60.0 \%$ \\
\hline DL8 & DL60 & 105 & 245 & 700 & 240 & $70.0 \%$ \\
\hline DL9 & DL60 & 70 & 280 & 700 & 240 & $80.0 \%$ \\
\hline
\end{tabular}

To assess material density, before tests specimens were weighted and their dimensions were measured.

Compressive tests were performed using universal testing machine Zwick Z100 (maximal applicable force $100 \mathrm{kN}$ ). Pressure on the specimens was applied in the same direction as compaction, by rate $10 \mathrm{~mm} / \mathrm{min}$, force - deformation diagram was recorded during the test.

Thermal conductivity was determined using Fox 600 heat flow measuring device. The sample was fixed horizontally. During the test temperature of lower surface was $+20^{\circ} \mathrm{C}$ and $0^{\circ} \mathrm{C}$ of upper surface (mean temperature $+10^{\circ} \mathrm{C}$ ). Heat transmission coefficient was determined considering constant heat flow between two sides of sample.

\section{Results and discussion}

\subsection{Composition of lime binders}

The testing to find the most suitable binder for hemplime material was done in several stages. The first stage included testing of air lime reactivity, the second searching for the most appropriate hydraulic additive and the third stage involved finding of the right dosage.

Table 4. Composition to test the reactivity of the additives

\begin{tabular}{lccccccccc}
\hline Sample name & $\begin{array}{c}\text { Lime, } \\
\text { type }\end{array}$ & $\begin{array}{c}\text { Lime, } \\
\mathrm{g}\end{array}$ & Add.1 & $\begin{array}{c}\text { Add.1, } \\
\mathrm{g}\end{array}$ & Add.2 & $\begin{array}{c}\text { Add.2, } \\
\mathrm{g}\end{array}$ & $\begin{array}{c}\text { Sand, } \\
\mathrm{g}\end{array}$ & $\begin{array}{c}\text { Water, } \\
\mathrm{g}\end{array}$ & $\begin{array}{c}\text { Hydraulic add., } \\
\%\end{array}$ \\
\hline D0 & DL60 & 350 & - & - & - & - & 700 & 240 & $0 \%$ \\
\hline D1 & DL60 & 280 & MT & 35 & FB & 35 & 700 & 240 & $20.0 \%$ \\
\hline D2 & DL60 & 250 & - & - & FB & 100 & 700 & 240 & $28.5 \%$ \\
\hline D3 & DL60 & 280 & MT & 35 & HB & 35 & 700 & 240 & $20.0 \%$ \\
\hline D4 & DL60 & 250 & - & - & HB & 100 & 700 & 240 & $28.5 \%$ \\
\hline D5 & DL60 & 280 & MT & 35 & CH & 35 & 700 & 240 & $20.0 \%$ \\
\hline D6 & DL60 & 250 & - & - & CH & 100 & 700 & 240 & $28.5 \%$ \\
\hline D7 & DL60 & 332.5 & MT & 17.5 & - & - & 700 & 240 & $5.0 \%$ \\
\hline D8 & DL60 & 315 & MT & 35 & - & - & 700 & 240 & $10.0 \%$ \\
\hline D9 & DL60 & 280 & MT & 70 & - & - & 700 & 240 & $20.0 \%$ \\
\hline D10 & DL60 & 341.75 & - & - & MS & 8.75 & 700 & 240 & $2.5 \%$ \\
\hline D11 & DL60 & 332.5 & - & - & MS & 17.5 & 700 & 240 & $5.0 \%$ \\
\hline D12 & DL60 & 341.75 & - & - & MS & 35 & 700 & 240 & $10.0 \%$ \\
\hline D13 & DL60 & 332.5 & MT & 8.75 & MS & 8.75 & 700 & 240 & $5.0 \%$ \\
\hline D14 & DL60 & 341.75 & MT & 17.5 & MS & 8.75 & 700 & 240 & \\
\hline D15 & DL60 & 332.5 & MT & 35 & MS & 8.75 & 700 & 240 & $7.5 \%$ \\
\hline
\end{tabular}




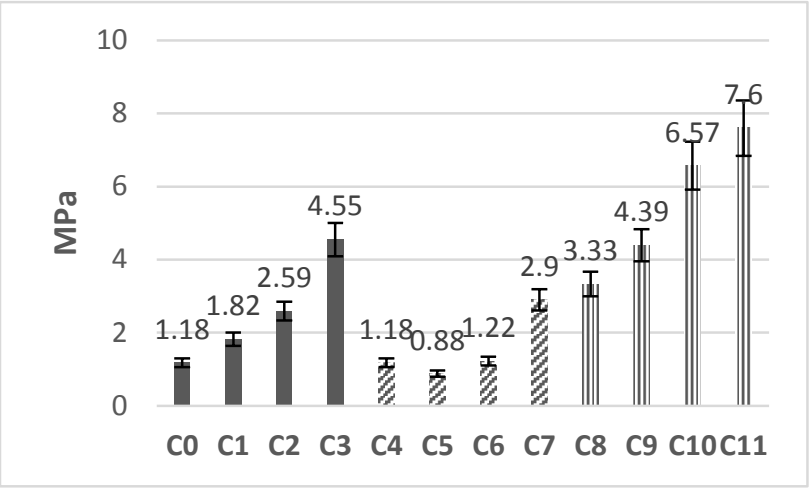

Fig. 3. Strength results of various air limes with metakaolin.

In the first stage of the research all three air limes were mixed with hydraulic additive - metakaolin - to test their reactivity. Mix compositions are summarized in Table 3. For every type of lime four different metakaolin proportions were used $-0,5,10$ and $20 \%$ of the total binder mass. Binder with sand ratio of 1:2 was used for all specimens. The amount of water necessary was determined by visually controlling and keeping consistent the flow of all binders.

The second stage was aimed at determining the most appropriate hydraulic additive for DL60 lime, which was the most active in the first stage, all five hydraulic materials were used in different compositions summarised in Table 4.

In the third stage the right dosage of the most suitable additive - metakaolin - was found, it was used form 0 up till $80 \%$ of the total binder mass, compositions are given in Table 5.

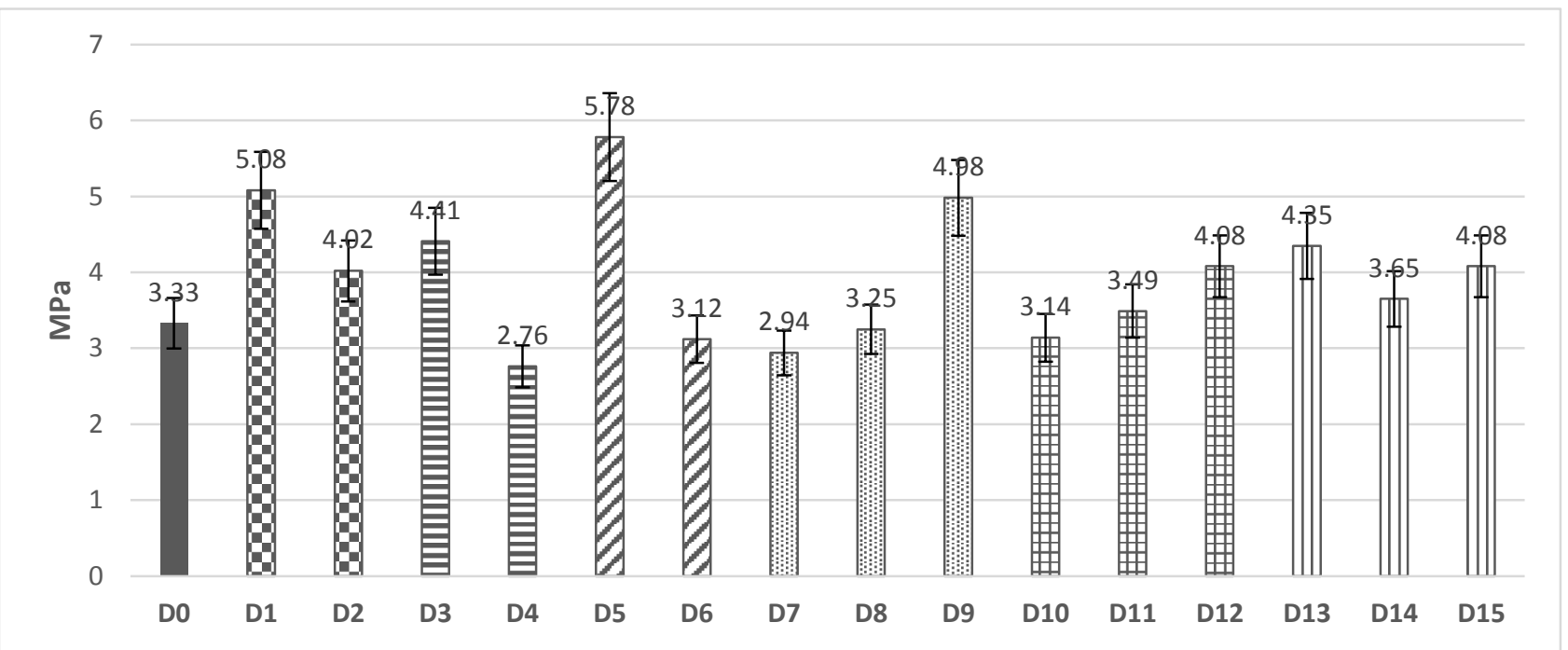

Fig. 4. Results of reactivity (mortar compressive strength) of various additives.

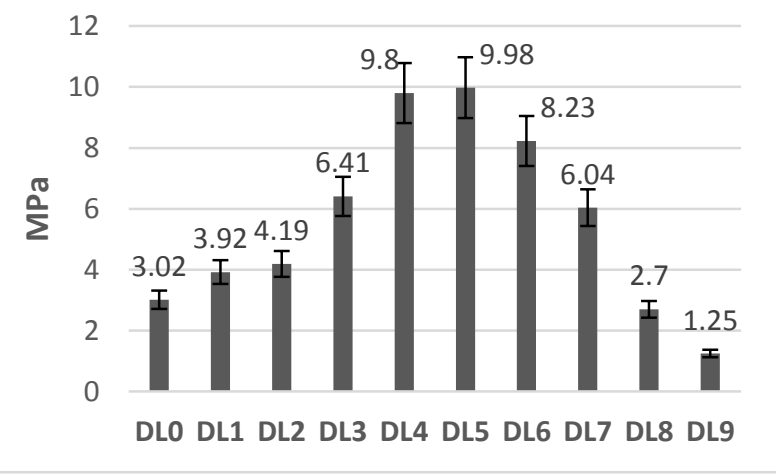

Fig. 5. Compressive strength of dolomitic lime with metakaolin.

\subsection{Compressive strength of the binder}

Results of the first stage of research are shown in Fig. 3. As it can be seen, addition of metakaolin significantly increases compressive strength of the binder, $20 \%$ addition to CL90 lime increases its strength almost four times, for CL80 lime about 2.5 times, but the highest value is achieved with DL60 lime with $20 \%$ metakaolin 7.6 MPa which compared to similar tests (Vejmelkova, et al. 2012) is above average, so for the next stages of research dolomitic lime was chosen.

From the results of the second stage (Fig. 4) it can be concluded that crushed brick and chammoete can be used only for replacement of more active hydraulic additive, as alone these materials contribute very little to strength increase. It can also be seen that microsilica alone or with metakaolin increase binder's compressive strength, but not as significantly as $20 \%$ MT addition.

Results of the third stage are shown in Fig. 5 and as it can be seen the highest value is achieved with $40 \%$ metakaolin addition to DL60 lime - after 28 days of curing - almost $10 \mathrm{MPa}$. This mixture will be used in further research as the binder for hemp-lime material.

\subsection{Characteristics of hemp-lime compositions}

In Table 5 mix proportions of three different shives/lime ratio compositions can be seen. The binder used is DL60 with $40 \%$ metakaolin addition. The ratios used are $0.31,0.38$ and 0.47 hemp/lime ratio by weight. The most commonly used out of all three is 0.38 (Miskin 2009), the other two are on both sides of the ratio scale to test the effect that density has on compressive strength and thermal conductivity. 
Table 5. Hemp-lime characteristics

$\begin{array}{lllll}\text { Nr. } & \begin{array}{l}\text { Hemp/ } \\ \text { binder } \\ \text { ratio }\end{array} & \begin{array}{l}\text { Density, } \\ \mathrm{kg} / \mathrm{m}^{3}\end{array} & \begin{array}{l}\text { Compressive } \\ \text { strength, MPa }\end{array} & \begin{array}{l}\text { Thermal } \\ \text { conductivity } \\ \lambda, \mathrm{W} / \mathrm{m}^{*} \mathrm{~K}\end{array}\end{array}$

\begin{tabular}{lllll}
\hline 1. & 0.31 & 337 & 0.222 & 0.0867 \\
\hline 2. & 0.38 & 328 & 0.221 & 0.0757 \\
\hline 3. & 0.47 & 312 & 0.179 & 0.1010 \\
\hline
\end{tabular}

It can be seen in Table 5 that hemp/lime ratio has the expected effect on density as higher ratio also means lower density. To test the compressive strength of the specimens, they were crushed on a Zwick 100 universal testing machine, which recorded a force-deformation diagram during the test. The force at $10 \%$ relative deformation $(10 \mathrm{~mm})$ is considered as the compressive strength of the samples. It can be observed that lowering the ratio below 0.38 does not provide any extra compressive strength $-0.222 \mathrm{MPa}$ for ratio 0.31 and $0.221 \mathrm{MPa}$ for 0.38 , increasing it does reduce it significantly to $0.179 \mathrm{MPa}$ at 0.47 . It can be explained that for this sieve granulometry the ratio of 0.38 is optimal as the binder can cover all the sieves to make an effective contact zone, increasing the amount of binder does not give any effect as the contact zone does not significantly change, but using smaller amount of binder creates spots with no binder coverage, which leads to lower compressive strength. It is possible to increase the compressive strength by adding even more binder, but it will have a negative effect on thermal conductivity. The results obtained (around $0.2 \mathrm{MPa}$ for $330 \mathrm{~kg} / \mathrm{m}^{3}$ ) can be considered as acceptable for using this material as a single layer self-bearing monolithic thermal insulation for low-rise buildings (Sinka et al. 2012).

Table 6. Hemp-lime corrected characteristics

$\begin{array}{lllll}\text { Nr. } & \begin{array}{l}\text { Hemp/ } \\ \text { binder } \\ \text { ratio }\end{array} & \begin{array}{l}\text { Density, } \\ \mathrm{kg} / \mathrm{m} 3\end{array} & \begin{array}{l}\text { Compressive } \\ \text { strength, } \mathrm{MPa}\end{array} & \begin{array}{l}\text { Thermal } \\ \text { conductivity } \\ \lambda, \mathrm{W} /(\mathrm{m} * \mathrm{~K})\end{array}\end{array}$

\begin{tabular}{lllll}
\hline 1. & 0.31 & 340 & 0.222 & 0.0753 \\
\hline 2. & 0.38 & 328 & 0.221 & 0.0722 \\
\hline 3. & 0.47 & 289 & 0.179 & 0.0696 \\
\hline
\end{tabular}

The results of thermal conductivity test can also be seen in Table 5. As expected the 0.31 sample produced a higher conductivity then 0.38 sample, because of lower amount of air pores, but the 0.47 showed even higher conductivity then 0.31 , which could be due to the fact that the specimen of the 0.47 sample was about two times wider and that not all of the water evaporated until the testing.

This was confirmed with repeated tests after 3 months of drying in indoor conditions. Final corrected results can be seen in Table 6 . The differences in material density were even more noticeable and thermal conductivity showed the results that were expected - that the specimen with the lowest density will also have the lowest thermal conductivity coefficient.

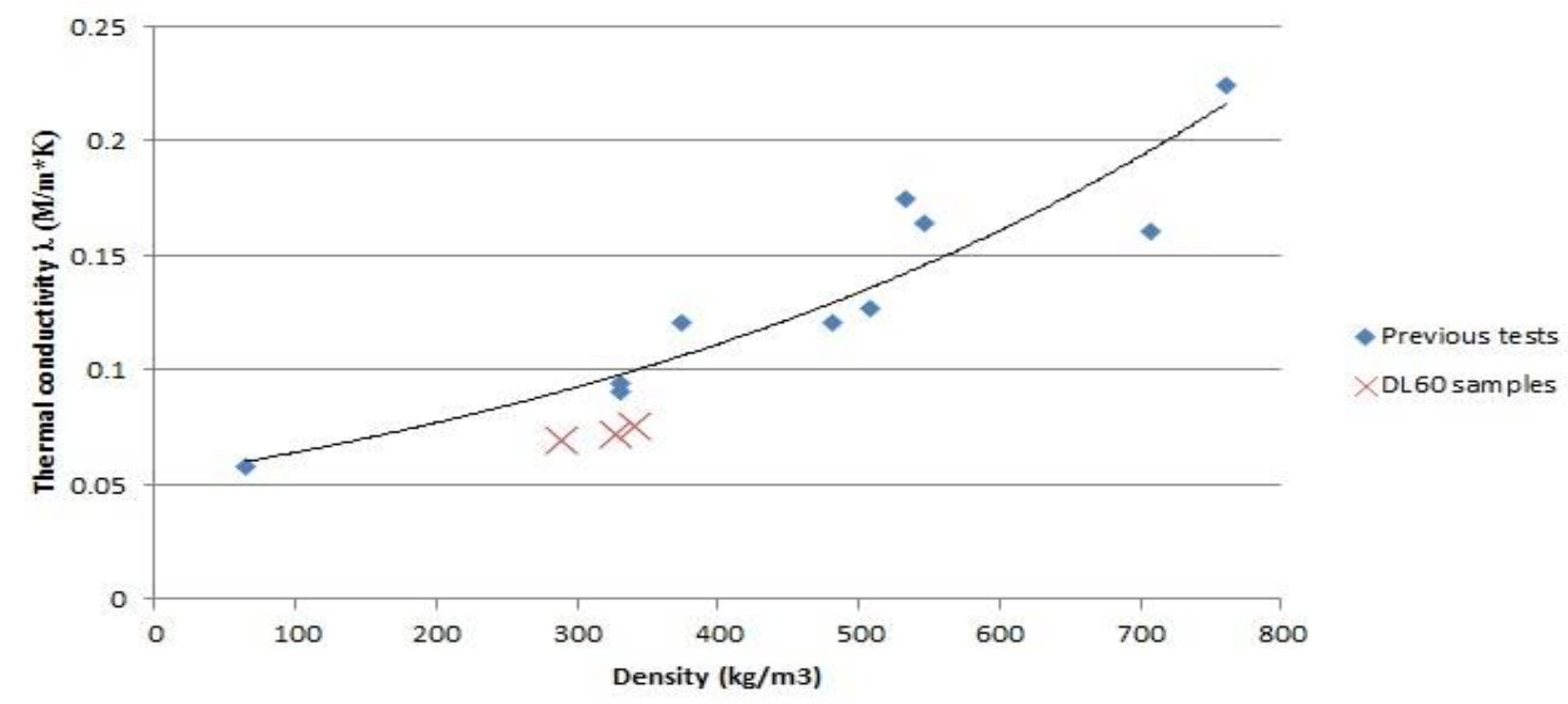

Fig. 6. Hemp-lime material thermal conductivity.

But if compared to results of previous tests in Fig. 6., it can be seen that the samples are a little bit below exponential trendline. And from that it can be concluded that the mixes created is considerable as acceptable and usable in development of hemp-lime thermal insulation materials (Sinka, Sahmenko 2013).

\section{Conclusions}

From the results of the first stage of experiment it can be concluded that the most rapid increase in compressive strength can be achieved using DL60 lime together with metakaolin $-40 \%$ by mass. CL90 and CL80 air limes showed lower reactivity, CL80 results were the lowest, which is explained with smaller amount of free lime. Other additives did not achieve high enough results to be 
used in hemp-lime materials, but have possible uses in the development of restoration mortars.

The results of the second stage showed that the chosen binder is suitable for hemp-lime materials, as it demonstrated compressive strength and thermal conductivity that is considered as acceptable for these materials.

The aim of this study was achieved as optimal natural binder composition was elaborated and sustainable thermal insulation material was created.

Further research in this field would require a more indepth research on other hemp-lime properties to facilitate comparing different binders used.

\section{References}

Benhelal, E.; Zahedi, G.; Shamsaei, E.; Bahadori, A., 2013. Global strategies and potentials to curb $\mathrm{CO}_{2}$ emissions in cement industry. Joranal of Cleaner production, pp. 142-161.

Bushbridge, R., 2009. Hemp-clay: an initial investigation into the thermal, structural and environmental credentials of monolithic clay and hemp [Online]. Graduate School at the Centre for Alternative Technology (cited 16.08.13). Available at: http://gse.cat.org.uk/public_downloads/ research/hemp/Ruth_Busbridge.pdf

Cerny, R.; Kunca, A.; Tydlitat, V.; Drchalova, J.; Rovnanikova P., 2006. Effect of pozzolanic admixtures on mechanical, thermal and hygric properties of lime plasters. Construction and Building Materials, 20, pp. 849-857. http://dx.doi.org/10.1016/j.conbuildmat.2005.07.002

Edwards, D.D., 2007. Pozzolanic properties of glass fines in lime mortar. Advances in Applied Ceramics, pp. 309-313. http://dx.doi.org/10.1179/174367607X228061

Florides, G.A.; Christodoulides, P.; Messaritis, V., 2013. Reviewing the effect of $\mathrm{CO}_{2}$ and the sun on global climate Renewable and Sustainable Energy reviews, 26, pp. 639-651. http://dx.doi.org/10.1016/j.rser.2013.05.062

Glaeser, E.L.; Kahn, M.E.; Wang, R.; Zheng, S., 2009. The Greenness of China. Harward Kennedy school (cited 16.08.13). Available at: http://www.hks.harvard.edu/m$\mathrm{rcbg} / \mathrm{heep} /$ papers/HEEP\%20Discussion\%2012.pdf

Hook, M.; Tang, X., 2012. Depletion of fossil fuels and anthropogenic climate change - A review. Energy Policy, 52, pp. 797-809.

http://dx.doi.org/10.1016/j.enpol.2012.10.046

Humlum, O.; Stordahl, K.; Solheim, J.E., 2012. The phase relation between atmospheric carbon dioxide and global temperature. Global and Planetar Change, 100, pp. 51-69. http://dx.doi.org/10.1016/j.gloplacha.2012.08.008

Miskin, N., 2013. The Carbon Sequestration Potential of Hempbinder. [Online]. Graduate School at the Centre for Alternative Technology (cited 16.08.13) Available at:
http://gse.cat.org.uk/public_downloads/research/hemp/N_Mi skin.pdf

Mosquera, M.J.; Silva, B.; Prieto B.; Ruiz-Harrera, E., 2004. Addition of cement to lime based mortars : Effect on pore structure and vapor transport. Cement and Concrete Research, 36, pp.1635-1642. http://dx.doi.org/10.1016/j.cemconres.2004.10.041

Pejic, B.; Kostic, M.; Skundric, P.; Praskalo, J., 2008. The effects of hemicelluloses and lignin removal on water uptake behaviour of hemp fibers. Bioresource Technology, 99, pp. 7152-7159.

http://dx.doi.org/10.1016/j.biortech.2007.12.073

Sinka, M.; Korjakins, A.; Sahmenko, G., 2012. The use of hemp shives with hydraulic lime binder in insulation materials. Proceedings of the Conference "Sustainable business under changing economic conditions", Turība, Rīga, pp. 305-313

Sinka, M.; Sahmenko, G., 2013. Sustainable Thermal Insulation Biocomposites from Locally Available Hemp and Lime. Environment. Technology. Resources. Proceedings of the $9^{\text {th }}$ International Scientific and Practical Conference, 1, pp. 73-77

Stevulova, N.; Terpakova, E.; Cigasova, J.; Junak, J.; Kidalova, L., 2012. Chemically treated hemp shives as a suitable organic filler for lightweight composites preparing. Procedia Engineering, 42, pp.948-954. http://dx.doi.org/10.1016/j.proeng.2012.07.488

Vejmelkova, E.; Keppert, M.; Rovnanikova, P.; Kersner, Z.; Cerny, R.; 2012. Application of burnt clay shale as pozzolan addition to lime mortar. Cement \& Concrete Composites, 34, pp. 486-492.

http://dx.doi.org/10.1016/j.cemconcomp.2012.01.001

Wang, Y.; Wang, W.; Mao, G.; Cai, H.; Zuo, J.; Wang, L.; Zhao, P., 2013. Industrial $\mathrm{CO}_{2}$ emissions in China based on the hypothetical extraction method: Linkage analysis. Energy policy. http://dx.doi.org/10.1016/j.enpol.2013.06.045

Wegian, F.M.; AlSaeid, H.M.; Alnaki, A.A., 2011. Effect of lime and fly ash on the strength of cement composite mortars. Australian Journal of Structural Engineering, 12, pp. 47-56.

Wilkinson, S., 2009. A Study of the Moisture Buffering Potential of Hemp in Combination with Lime and ClayBased Binders. Graduate School at the Centre for Alternative Technology. Available at: http://gse.cat.org.uk/ public_downloads/research/hemp/Simon_Wilkinson.pdf

Xu, J.H.; Fleiter, T.; Eichhammer, W.; Fan, Y., 2012. Energy consumption and $\mathrm{CO}_{2}$ emissions in China's cement industry: A perspective from LMDI decomposition analysis. Energy policy, pp.821-832. http://dx.doi.org/10.1016/j.enpol.2012.08.038 